\title{
Effect of Electrolysis Treatment Time, Field Strength and Recycling Flowrate on Ankistrodesmus sp. Lipid Extraction
}

\author{
C. Joannes ${ }^{{ }^{*}}$, C.S. Sipaut ${ }^{1}$, S.M. Yasir ${ }^{2}$, J. Dayou ${ }^{3}$ and R.F. Mansa ${ }^{1}$ \\ ${ }^{1}$ Energy and Materials Research Group (EMRG), Faculty of Engineering, Universiti Malaysia Sabah (UMS), \\ 88400 Kota Kinabalu, Sabah, Malaysia \\ ${ }^{2}$ Seaweed Research Unit (UPRL), Faculty of Science and Natural Resources, Universiti Malaysia Sabah (UMS), \\ 88400 Kota Kinabalu, Sabah, Malaysia \\ ${ }^{3}$ Energy, Vibration and Sound Research Group (e-VIBS), Faculty of Science and Natural Resources, \\ Universiti Malaysia Sabah (UMS), 88400 Kota Kinabalu, Sabah, Malaysia
}

\begin{abstract}
The study discusses the effect of Electrolysis Ereatment (ET) parameters focussed on the Electrolysis Treatment Time (ETT), Electrolysis Field Strength (EFS) and Electrolysis Recycling Flowrate (ERF) towards Ankistrodesmus sp. lipid extraction prior to the solvent extraction method. In the ET system selection experiment, the highest lipid content $(13.05 \pm 0.57 \%$ wt.) attained was from ET system $3(21 \mathrm{~V} / \mathrm{cm}, 140 \mathrm{ml} / \mathrm{min}$ and $25 \mathrm{~min})$. The three ET parameters were then optimized. The highest lipid content and methyl palmitate gained in ETT was $15.83 \pm 0.68 \%$ wt. and $0.440 \pm 0.046 \mu \mathrm{g} / \mathrm{ml}$ at $20 \mathrm{~min}$, respectively. Meanwhile, the highest lipid content and methyl palmitate obtained in EFS was $15.46 \pm 0.78 \%$ wt. and $0.629 \pm 0.058 \mu \mathrm{g} / \mathrm{ml}$ at $21 \mathrm{~V} / \mathrm{cm}$, respectively. As for ERF, the highest lipid content and methyl palmitate attained was $15.60 \pm 0.67$ $\%$ wt. and $0.390 \pm 0.032 \mu \mathrm{g} / \mathrm{ml}$ at $180 \mathrm{ml} / \mathrm{min}$, respectively. In comparison to Ankistrodesmus sp. Without Electrolysis Treatment (WOET), the lipid extraction of Ankistrodesmus sp. treated With Electrolysis Treatment (WET) can be improved and had resulted in the increasing of extraction with 1.34, 1.38 and 1.40 times higher in ETT, EFS and ERF, respectively.
\end{abstract}

Keywords: Ankistrodesmus sp.; electrolysis treatment; lipid extraction; lipid content; methyl palmitate

\section{INTRODUCTION}

It is undeniable that humans are still relying on fossil fuel resources for transportation, heat generating and electricity purpose. The concerning part is that all of these natural resources soon will be diminished and will not be adequate to support the people's necessities worldwide. Moreover, it takes millions of years to wait for these fossil fuels to form again. For that reason, seeking other alternative energy for fossil fuel replacement is crucial and urgent. Biodiesel is a renewable and sustainable energy that can lessen fossil fuels utilisation as well as reduces the global warming impact, which is primarily contributed from fossil fuels combustion (IEA, 2017). To date, the interest in using microalgae-based biodiesel has become more significant. High lipid content, rapid growth rate, less land for cultivation, flexible to grow under various climates, and none food security related are some of the unique features of microalgae (Joannes et al., 2016; Mansa et al., 2018a, 2012). In this study, Ankistrodesmus sp. was used because it has shown a very promising feedstock for biodiesel. This green freshwater microalga is capable of producing lipid around 32.4 to $57.7 \%$ wt as well as enrich with monosaturated fatty acids such as palmitic acid (Sukkrom et al., 2014).

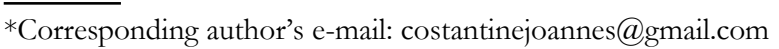


The microalga's lipid is one of the secret ingredients in biodiesel formation. The lipid is stored inside the microalga and is sturdily protected by its rigid cell wall, which is composed of cellulose, lipid, glycoprotein, polysaccharide and protein (Lee et al., 2017). In other words, the cell wall is the major bottleneck in microalga lipid extraction. Hence, the cell wall must be broken to facilitate the lipid extraction process (acylglycerols and free fatty acids). Therefore, lipid extraction is relatively a challenging stage. Some researchers had used mechanical cell wall disruptions (e.g. high-pressure homogenizer, hydrodynamic, ultrasonication, microwave, Pulse Electric Field (PEF) and hydrothermal liquefaction) or nonmechanical cell wall disruptions (e.g. acid treatment, ionic liquid, osmotic shock, solvent extraction, supercritical fluid extraction, oxidation, surfactant, enzymatic lysis and algicidal treatment) to extract the lipid from microalgae (Günerken et al., 2015; Joannes et al., 2015b). Nonetheless, some drawbacks such as energy intensive, upscaling, time-consuming, chemicals safety, high capital investment, costly raw materials and highly precarious involving electrical based extraction (Mubarak et al., 2015). Thus, numbers of researchers have combined mechanical and non-mechanical methods to improve lipid extraction efficiency.

Apart from these extraction methods, another recent approach which is using an Electrolysis Treatment (ET) as a prelude for microalgae lipid extraction (Mansa et al., 2018a). The benefits of ET such as it uses lower voltage range ( $\sim 6-30 \mathrm{~V})$, simple operation, cheaper, lighter, easy to construct and clean. Conventionally, ET method is used in microalgae harvesting with an electrolyte addition and typically conducted under a batch system (Baierle et al., 2015; Uduman et al., 2011; Zhou et al., 2016). The process of collecting the microalga cells using ET is called electrophoresis. In nature, microalga cells are negatively charged, and the cells will move to the anode (positive terminal) and then coagulate due to the potential difference between the anode and cathode (Uduman et al., 2010). In other theory, exposing the microalga cells to electric fields at a certain level (higher than the cell membrane critical strength) will cause the cell to experience irreversible or reversible cell electroporation. Irreversible cell electroporation is the condition where the cell membrane is unable to reseal back to its original form whereas, reversible cell electroporation is the opposite condition of irreversible cell electroporation (Joannes et al., 2015a, 2015b; Mansa et al., 2018b). When the cell membrane is broken, the valuable components like lipid, protein and carbohydrate will be exposed to the surrounding and easily can be extracted. In the meantime, only a few available literatures were published with regards to microalga lipid extraction using the ET method (Daghrir et al., 2014; Guldhe et al., 2016; Hua et al., 2016; Misra et al., 2015, 2014). This method is still under development and is considered to be a new approach to microalga lipid extraction.

Henceforth, as the continuity from the preliminary study conducted by Mansa et al. (2018b), this work aims to demonstrate the ET method as the pre-treatment for microalga lipid extraction and investigating the effect of Electrolysis Treatment Time (ETT), Electrolysis Field Strength (EFS) and Electrolysis Recycling Flowrate (ERF) on the lipid extraction of Ankistrodesmus sp. However, erstwhile to this investigation, the determination of the best ET systems in the combinations of recycle, without recycle, aeration and/or without aeration, was employed. The types of Fatty Acid Methyl Esters (FAME) in Ankistrodesmus sp. after the ET extraction was also determined, and the amount of methyl palmitate (C16:0) extracted was revealed in this study.

\section{MATERIALS AND METHOD}

\section{A. Microalga Cultures}

Ankistrodesmus sp. was obtained from Borneo Marine Research Institute (BMRI), Universiti Malaysia Sabah, Malaysia. The microalga was cultured phototrophically in sterilized freshwater enriched with Bold's Basal medium (BBM). The cells length were between 14.7-38.1 $\mu$ m (Mansa et al., 2018a). The microalga was pre-cultured in a 500ml, 2000ml and 5000ml Erlenmeyer flask before it was upscaled into a $10,000 \mathrm{ml}$ vessel at $32.1 \pm 0.7^{\circ} \mathrm{C}, \mathrm{pH}$ $8.02 \pm 0.07$ and 12:12 h light-dark cycle under a light intensity of $999 \pm 15$ Lux for seven days of cultivation.

\section{B. Extraction Procedures}

\section{Electrolysis treatment chamber design}

The schematic diagram of ET chamber was shown in Figure 1. The electrolysis treatment (ET) chamber was fabricated 
from an acrylic material with dimensions of $0.179 m$ (length) $\mathrm{x} \quad 0.152 \mathrm{~m}$ (height) $\mathrm{x} \quad 0.057 \mathrm{~m}$ (width) and $0.005 \mathrm{~m}$ (thickness). The stainless steel plate electrode dimensions were $0.153 \mathrm{~m}$ (length) $\mathrm{x} 0.114 \mathrm{~m}$ (height) and $0.0004 \mathrm{~m}$ (thickness). Four bolts with five hexagonal nuts and four flat washers were used as the holder for the stainless steel plate electrode. The gap between the electrodes was fixed at $0.015 \mathrm{~m}$. Straight pipe fitting tubes were used for the inlet/outlet connector of the ET chamber. Four pneumatic flow control valves, hose to hose connector and $2.2 \mathrm{~m}$ silicone tube were used so that the microalga can be recycled back to the ET chamber. The inlet and outlet flow were placed at the same level.

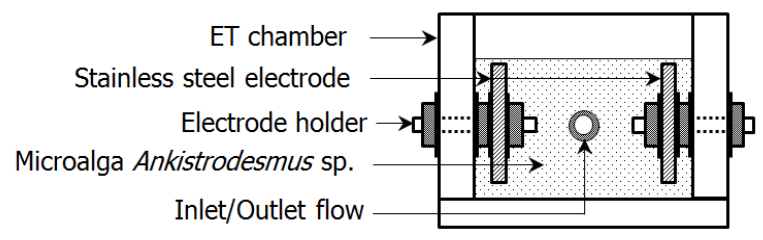

Figure 1. Schematic diagram of the ET chamber from the front view

\section{Electrolysis treatment experimental setup}

\section{i. Selection of ET system}

Three systems of ET were varied based on the combinations of aeration, without aeration, recycle and/or without recycle. The stainless steel plates were connected to a DC power supply (MP 303-3, Meguro). For the recycling and aeration flow, a peristaltic pump (Pump Drive PD 5006, Heidolph) and an air pump (AC-9980, Resun $\left.{ }^{\circledR}\right)$ were used, respectively. Meanwhile, the sample flow rate was measured using a digital flow rate meter (T14 Flo-meter, McMillan Co.). Four types of treatment conditions for the ET system were carried out; (1) condition was without ET, Recycling Flowrate (RF) and Aeration Flow (AF); (2) condition (ET system 1) which undergone the ET only; (3) condition (ET system 2) which undergone the ET with RF only; (4) condition (ET system 3) which undergone the ET with RF and AF. The ETT, EFS, RF, AF, microalga volume and concentration were fixed at $25 \mathrm{~min}, 21 \mathrm{~V} / \mathrm{cm}$, $140 \mathrm{ml} / \mathrm{min}, 100 \mathrm{ml} / \mathrm{min}, 1000 \mathrm{ml}$ and $\sim 1.00 \mathrm{~g} / \mathrm{l}$, respectively. All treatments were conducted in triplicates, and the data presented were in average value \pm standard errors.

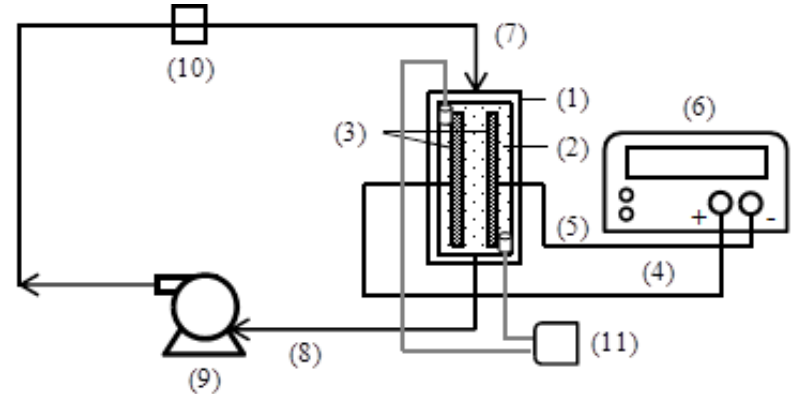
(1) ET chamber
(7) Inlet flow
(2) Microalga Ankistrodesmus sp.
(3) Stainless steel electrodes
(4) Anode $(+)$
(5) Cathode (-)
(6) DC power supply
(8) Outlet flow
(9) Peristaltic pump
(10) Flowmeter
(11) Aerator pump

Figure 2. Schematic diagram of the experimental setup for the ET method

\section{ii. Experimental design parameters}

The schematic diagram of ET set up, as shown in Figure 2. Then, solvent extraction was carried out for further lipid extraction. The first parameter conducted was the ETT and varied at 10, 15, 20, 25, 30, 35 and 40 min at constant EFS $(21 \mathrm{~V} / \mathrm{cm})$ and $\mathrm{ERF}(14 \mathrm{Oml} / \mathrm{min})$. The second parameter was the EFS and varied at $6,9,12,15,18$ and $21 \mathrm{~V} / \mathrm{cm}$ at constant ETT (20 min) and ERF (140ml/min). The third parameter was the ERF and varied at 140, 160, 180, 200, 220 and $240 \mathrm{ml} / \mathrm{min}$ at constant ETT $(20 \mathrm{~min})$ and EFS $(21 \mathrm{~V} / \mathrm{cm})$. The highest lipid obtained in ETT condition was selected and used in EFS. The same procedure was applied in the ERF experiment. Solvent extraction was carried out after the ETT, EFS and ERF experiment for further lipid extraction. All the above experiments were performed in triplicates, and the data presented were average value \pm standard errors.

\section{Solvent extraction}

Ankistrodesmus sp. lipid was extracted from its dried biomass according to Folch method (Folch et al., 1957). After the ET method, all samples were centrifuged (3-18K Sartorius, Sigma) at 8,00orpm for $15 \mathrm{~min}$ and dried into an oven (UNE 200, Memmert) at $70 \pm 1^{\circ} \mathrm{C}$ for $24 \mathrm{~h}$. The dried biomass was placed inside a desiccator and then left for a few minutes for cooling at room temperature. A solvent mixture of $8 \mathrm{ml}$ chloroform and $4 \mathrm{ml}$ methanol $\left(\mathrm{CHCl}_{3}-\right.$ $\mathrm{MeOH} ; 2: 1 ; \mathrm{v} / \mathrm{v}$ ) were mixed with the dried microalga using a magnetic stirrer (HSo707V2, Favorit) at 850rpm for 10 
min. Then, the biomass (solid phase) was filtered using a filter paper. Meanwhile, the liquid phase (a mixture of $\mathrm{CHCl}_{3}-\mathrm{MeOH}$ ) was placed into a new clean universal bottle and $2.4 \mathrm{ml}$ distilled water was added into the liquid phase for washing. The liquid phase contained water was stirred at 115 orpm for $1 \mathrm{~min}$ to allow the formation of the lipidsolvent molecules and at 850 orpm for $4 \mathrm{~min}$ for the two layers formation. The bottom layer consisted of $\mathrm{CHCl}_{3}$ and lipid, whereas the top layer consisted of $\mathrm{MeOH}$-water and non-lipids. The bottom layer was collected using a glass Pasteur pipette and placed into a new clean universal bottle.

\section{The potential difference of cell membrane estimation}

The potential difference of the cell membrane can be estimated using Equation 1 (Ortega-Rivas, 2012).

$$
U m=\alpha d_{c} E \cos \theta
$$

Where;

The potential difference of the cell membrane $=U_{m}(V)$

The parameter based on cell shape $=\alpha$ (dimensionless)

The cell diameter $=\mathrm{d}_{\mathrm{c}}(\mu \mathrm{m})$

The external electric field $=\mathrm{E}(\mathrm{V} / \mathrm{cm})$

The angle between the sites on the cell membrane $=\Theta$

\section{The potential difference of cell membrane estimation}

\section{i. Light microscopic}

A light microscope (Eclipse 90i, Nikon) was used to view the Ankistrodesmus sp. cells before and after the ET method. An approximately $10 \mathrm{ml}$ of each sample was taken for cells observation. The magnification power used to view the microalga cells was $40 \mathrm{X}$.

\section{ii. Scanning electron microscopy (SEM)}

The surface morphology of the Ankistrodesmus sp. cells were examined by Scanning Electron Microscopy (SEM) (Carl Zeiss, EVO MA 10). The SEM sample preparation was performed based on chemical fixation method, and the procedures were followed according to Mansa et al. (2018a).

\section{Lipid content determination}

The lipid content was determined based on the gravimetric method. The procedures were followed according to Mansa et al. (2018a). The lipid content was calculated using Equation 2.

$$
\text { Lipid content }(\% w t)=\left[\frac{\text { glipid microalga }}{\text { gdried microalga }}\right] \times 100 \%
$$

\section{Lipid functional group determination}

A Fourier Transform Infrared Spectroscopy (FTIR) (2000 Series, Perkin-Elmer) was used to determine the functional groups of lipid for all samples. The procedures were followed according to Mansa et al. (2018a).

\section{Transesterification process}

A base catalyst (potassium hydroxide, $\mathrm{KOH}$ ) was used for the FAME conversion, and the procedures were followed according to Mansa et al. (2018a).

\section{Fatty acid methyl ester composition}

A Gas Chromatography-Mass Spectrophotometer (GCMS) (Model 689oN, Agilent Technologies) was used to determine the FAME compositions. The procedures were followed according to Mansa et al. (2018a).

\section{RESULTS AND DISCUSSION}

\section{A. Lipid Functional Groups of Ankistrodesmus sp.}

\section{In ET system varied conditions}

The FTIR spectrum for each sample was shown in Figure 3. The lipid functional groups were all detected in each sample for solvent extraction without ET and with ET method (ET system 1, 2 and 3). The $\mathrm{C}-\mathrm{H}$ stretching vibration was obtained at $3010 \mathrm{~cm}^{-1}$ representing the stretching of $=\mathrm{C}-\mathrm{H}$ bond, at $2855 \mathrm{~cm}^{-1}, 2925 \mathrm{~cm}^{-1}$ and $2954 \mathrm{~cm}^{-1}$ representing the stretching of $\mathrm{C}-\mathrm{H}$ bonds in $-\mathrm{CH}_{3}$ and $\mathrm{CH}_{2}$. It was presented that, $\mathrm{C}=\mathrm{O}$ bond found in the ester group was detected at $1740 \mathrm{~cm}^{-1}$, which was primarily obtained from lipid and fatty acids compound (Dean et al., 2010). Besides that, $\mathrm{C}-\mathrm{O}$ bond and $\mathrm{C}-\mathrm{O}-\mathrm{C}$ bond was also detected at $138 \mathrm{ocm}^{-1}$ and $1250-$ $1070 \mathrm{~cm}^{-1}$ which also came from the ester group, respectively (Forfang et al., 2017). The peak at $1460 \mathrm{~cm}^{-1}$ was also 
obtained, indicating the bending of $\mathrm{CH}_{2}$ bond (Bartošová et al., 2015).

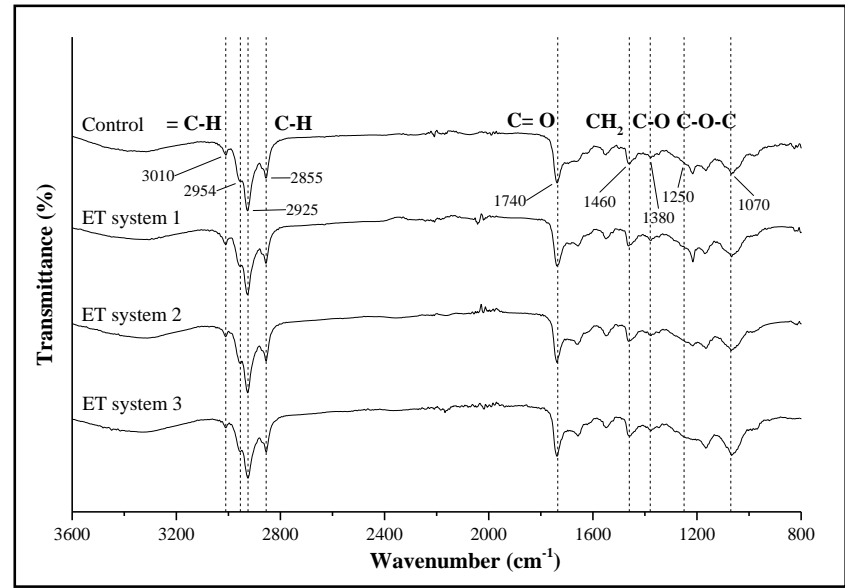

Figure 3. FTIR spectra of Ankistrodesmus sp. in the control sample and different ET system

\section{In ETT, EFS and ERF condition}

The FTIR spectra for ETT, EFS and ERF performed solvent extraction with the ET method were displayed in Figure 4. Figure $4 \mathrm{a}, 4 \mathrm{~b}$ and $4 \mathrm{c}$ showed the FTIR spectra from ETT, EFS and ERF samples, respectively. The lipid functional groups were found to be similar to the lipid profiles presented in Figure 3. In Figure 4a, the highest peak intensity was obtained from ETT2O followed by ETT25, ETT30, ETT35, ETT40, ETT15, ETT10 and ETTo. Meanwhile, the highest peak intensity was obtained from EFS21 followed by EFS18, EFS15, EFS12, EFS9, EFS6 and ETTo, as shown in Figure 4b. For EFS, the highest peak intensity was obtained from ERF180 followed by ERF20o, ERF220, ERF240, ERF160, ERF140 and ERFo. From these FTIR spectra, it shows that higher peak intensity corresponded to the higher lipid content that was extracted from the sample (Forfang et al., 2017).

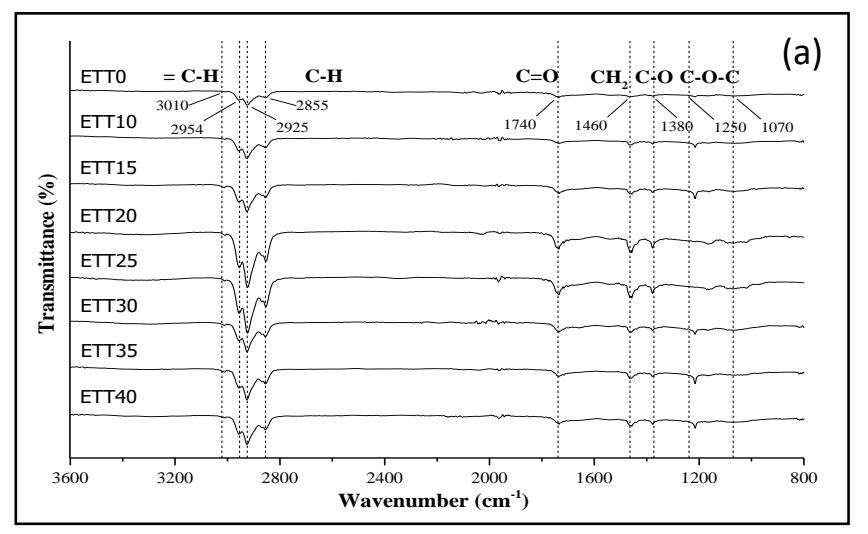

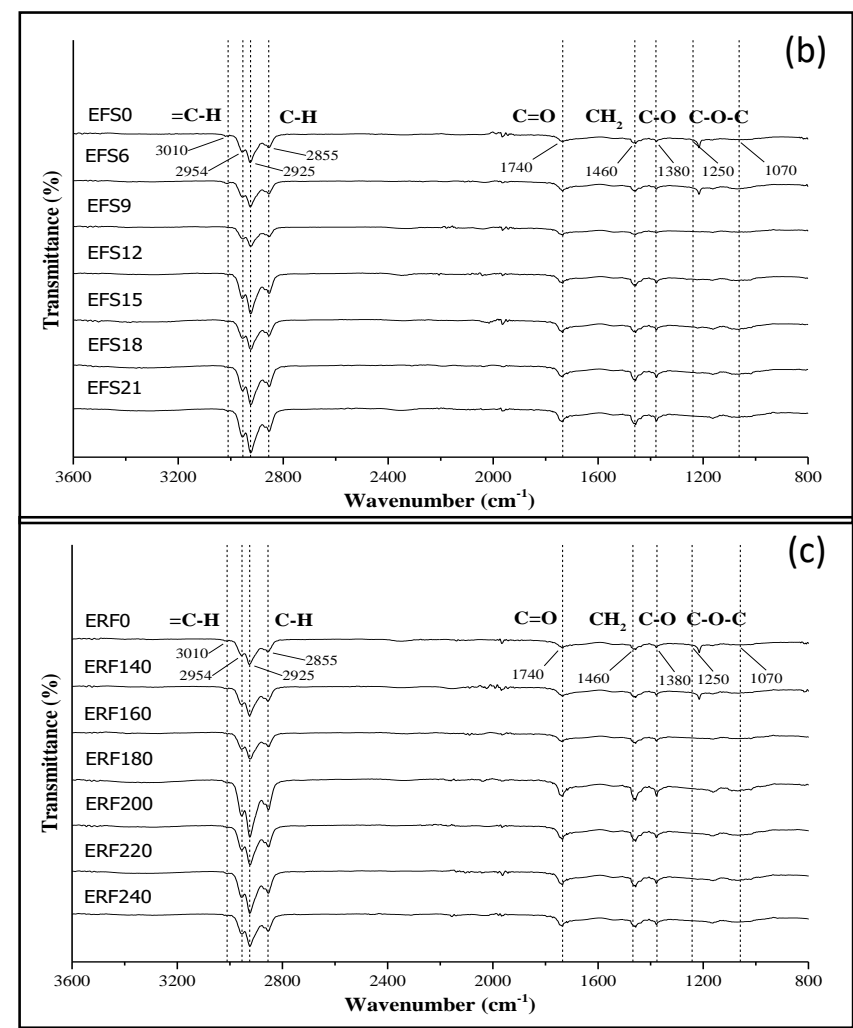

Figure 4. FTIR spectra of Ankistrodesmus sp. in (a) ETT, (b) EFS and (c) ERF samples

\section{B. Lipid Content}

\section{Effect of ET}

The effect of the ET system on the lipid content of Ankistrodesmus sp. was shown in Figure 5a. Based on Figure 5a, the highest lipid content extracted was obtained from ET system 3 with $13.05 \pm 0.57 \%$ wt. followed by ET system 2, the control sample, and ET system 1 with $12.91 \pm$ $0.85 \%$ wt., $11.15 \pm 0.73 \%$ wt. and $10.26 \pm 0.41 \%$ wt., respectively. Except for ET system 1, all samples that had undergone the ET method showed higher lipid content compared to the control sample.

Higher lipid content was attained from the ET system three due to $\mathrm{RF}$ and $\mathrm{AF}$ systems were introduced into the system. The microalga cells were well mixed and had higher chances of passing through the electric field region. Thus, it provided a higher probability of the cell membrane to be disturbed or weaken. This facilitated the solvent molecules to penetrate deeper into the cell and allow it to extract the lipid that stored inside the lipid granule (Eing et al., 2013; Guldhe et al., 2016). In ET system 2, only RF was introduced, thereby, explained the difference in lipid 
content extracted from ET system 3. However, the lipid content obtained from the ET system 1 was lower compared to the control sample. The reasonable explanation for this result was because of the oxidation of lipids may be occurred along with the experiment (Daghrir et al., 2014). Apart from the surrounding oxygen gas, the ET also produced oxygen gases at the anode. Thus it can contribute to the increase of lipid oxidation. The lipid oxidation can also occur in ET system 2 and system three as the anode electrode undergoes an oxidation process while the cathode undergoes the reduction process.

However, the condition in the ET system one might be an extreme condition for the Ankistrodesmus sp. lipid extraction as compared to the other two methods. Misra et al. (2014) had discovered that using an electrochemical treatment (non-sacrificial carbon electrode) the final lipid content of Chlorella sorokiniana (12.20\% wt.) and Scenedesmus obliquus (15.42\% wt.) were $0.17 \%$ and $0.14 \%$ lower than the control sample, respectively. This indicates that using ET without AF and RF do not improve the lipid extraction but can contribute to lower lipid extraction with only slightly different. Mansa et al. (2018b) had observed that using ET with AF, the final lipid attained of Chlorella sp. was $0.86 \%$ or 1.11 times lower than the WOET sample. The effect ET system towards the cell appearances and amount of extracted lipid were summarized in Table 1.

Table 1. Cell observation and total lipid based on different ET system

\begin{tabular}{|l|c|c|c|c|}
\hline \multicolumn{1}{|c|}{ System } & Control & System 1 & System 2 & System 3 \\
\hline $\begin{array}{l}\text { Treatment system } \\
\text { conditions }\end{array}$ & $\begin{array}{c}\text { without ET, RF } \\
\text { and AF }\end{array}$ & $\begin{array}{c}\text { with ET but } \\
\text { without RF and } \\
\text { AF }\end{array}$ & $\begin{array}{c}\text { with ET and RF } \\
\text { but without AF }\end{array}$ & $\begin{array}{c}\text { with ET, RF and } \\
\text { AF }\end{array}$ \\
\hline $\begin{array}{l}\text { Batch/Semi-continuous } \\
\text { system }\end{array}$ & - & batch & semi- \\
continuous & continuous \\
\hline Final temperature $\left(^{\circ} \mathrm{C}\right)$ & $25.1 \pm 0.1$ & $48.4 \pm 0.1$ & $45.4 \pm 0.1$ & $43.0 \pm 0.1$ \\
\hline Final pH & $8.55 \pm 0.01$ & $10.12 \pm 0.01$ & $9.21 \pm 0.01$ & $8.94 \pm 0.01$ \\
\hline Conductivity $(\mu \mathrm{S} / \mathrm{cm})$ & $1160 \pm 1$ & $1966 \pm 3$ & $1809 \pm 2$ & $1792 \pm 3$ \\
\hline The cells appearance after & $\begin{array}{c}\text { Non-flocculate } \\
\text { and non-fluffy- } \\
\text { the ET method }\end{array}$ & $\begin{array}{c}\text { flocculate and } \\
\text { fluffy-like }\end{array}$ & fluffy-like & fluffy-like \\
\hline Lipid content $(\%$ wt.) & $11.15 \pm 0.73$ & $10.26 \pm 0.41$ & $12.91 \pm 0.85$ & $13.05 \pm 0.57$ \\
\hline
\end{tabular}

\section{Effect of ETT}

The effect of ETT on the extraction of microalga lipid from zero to 40 min was displayed in Figure $5 \mathrm{~b}$. The lipid content obtained from sample WOET (ETTo) was $11.83 \pm 0.81 \%$ wt. All samples WET (ETT10 - ETT40) had produced higher lipid content than sample WOET. According to these chart bars, the lipid content extracted from Ankistrodesmus sp. increased from 10 to $20 \mathrm{~min}$. However, the lipid content had decreased from 20 to $40 \mathrm{~min}$. The amount of lipid content extracted was the highest at 20 min, with $15.83 \pm$ $0.68 \%$ wt. and lowest at 10 min with $13.59 \pm 0.94 \%$ wt.

The entire lipid content attained in samples WET were higher than sample WOET due to ET was used as pre- extraction. Increasing the PEF treatment time will also rapidly increase the rate of microbes' inactivation, then slowly plateau and further treatment will show no significant change (Huang \& Wang, 2009). Hence, to correlate the above statement with the present study, the extraction of Ankistrodesmus sp. lipid increased from 10 to 20 min because, during this period, the cell's membrane was experienced vigorous irreversible electroporation. The lowest lipid content attained was at 10 min because the cells had the lowest exposure time. Meanwhile, the highest lipid content extracted was at 20 min and extraction duration longer than 20 min will cause an extreme extraction process, which contributes to the decrease of lipid content extraction from 20 to $40 \mathrm{~min}$. The results obtained here agreed with 
other reported literatures. As reported by Daghrir et al. (2014), increasing the electrochemical treatment time between 60 to $100 \mathrm{~min}$ will enhance $C$. vulgaris lipid content between 3.33 to $3.55 \%$ wt., respectively. In fact, by increasing the PEF treatment time between 1 to $3 \mathrm{~min}$ had shown to increase the percentage of Chlorella sp. disrupted cells from 40 to 90\% (Rego et al., 2015).

Unfortunately, increasing the treatment time above than $20 \mathrm{~min}$, the lipid content decreased. The possible explanation for this condition was because of the lipid being oxidized. In theory, at a certain point, further treatment of the microbe inactivation will show no significant change (Huang \& Wang, 2009). However, because of the oxidation mechanism due to the presence of oxygen gases either from the surrounding or released from the anode terminal, will cause some of the extracted lipid to oxidize. The degradation of lipid can be due to hydrolysis or oxidation mechanism, and this can be attributed by photo-oxidation, auto-oxidation or enzymatic-oxidation reactions (Meullemiestre et al., 2016). It is also essential to take note that, when the treatment time is increased, the current intensity also increase and this had will cause the sample's temperature to rise. Thereby, it may affect the valuable components such as lipid that released into the surrounding medium to oxidize (Daghrir et al., 2014; Mansa et al., 2018b). This may indicate that the lipid has undergone an oxidation process. Therefore, this lipid oxidation may attribute to the lowering of Ankistrodesmus sp. lipid content.

\section{Effect of EFS}

The effect of EFS on the extraction of microalga lipid is shown in Figure $5 \mathrm{c}$. The lipid content gained in sample WOET (EFSo) was $11.19 \pm 0.76 \%$ wt. As expected, if the EFS value increased the lipid content of Ankistrodesmus sp. extracted was also increased. Same as in ETT, the lipid content from the samples WET (EFS6 - EFS21) were higher than the sample WOET. The highest lipid content was achieved at $21 \mathrm{~V} / \mathrm{cm}$ with $15.46 \pm 0.78 \%$ wt. and the lowest lipid content was at $6 \mathrm{~V} / \mathrm{cm}$ with $11.36 \pm 0.79 \%$ wt.

As stated by Donsì and co-workers, most of the cell membrane has a critical transmembrane potential around 0.2 to 1.oV (Donsì et al., 2010). However, the cell membrane potential calculated in this study was much lower than $0.2 \mathrm{~V}$. The potential difference of the cell membrane of microalga $\left(\mathrm{U}_{\mathrm{m}}\right)$ can be estimated using the Equation $1\left(\mathrm{U}_{\mathrm{m}}=\right.$ $\left.\operatorname{ad}_{c} E \cos \theta\right)$. In this study, the structure of Ankistrodesmus sp. cells were observed to have a needle-like shape and curvy or sharp at both edges as reported by Mansa et al. (2018b). By considering the Ankistrodesmus sp. cell with almost a rectangular shape ( $\alpha=1.0$; considering the middle part of the cell) and the cell width $(0.3-2 \mu \mathrm{m} ; 0.3 \mu \mathrm{m}$ is based on literature, and $2 \mu \mathrm{m}$ is the width obtained in this study see Figure $7 \mathrm{a}$ ), the potential difference can be attained around $1.8 \times 10^{-4}$ to $1.2 \times 10^{-3} \mathrm{~V}$. Thus, using $6 \mathrm{~V} / \mathrm{cm}$ and above can disrupt most of the cells.

Besides that, the result attained here was supported by other reported literatures. Heinz et al. (2003) stated that increasing the electric field strength will also increase treatment efficiency. Applying higher field strength on the microalga (above the critical strength of the cell membrane) will increase the cell membrane permeability by making the cell membrane to become irreversible electroporation (Joannes et al., 2015b; Zbinden et al., 2013; Zimmermann et al., 1974). This will assist the solvent molecules that were added to penetrate the microalga's cell. Hence, this explained that the lipid content extracted has increased as the EFS increased. Based on the graph, the optimum value for EFS has not yet achieved, because the highest voltage that can be used was up to $31.4 \mathrm{~V}$ only, due to the equipment limitation (i.e. DC power supply). Higher EFS $(\geq 21 \mathrm{~V} / \mathrm{cm})$ can be obtained if the gap between the two electrodes (d) is reduced. However, in this study, the smallest gap used was $0.015 \mathrm{~m}$ and was fixed for the entire experiment.

\section{Effect of ERF}

The effect of ERF on the extraction of microalga lipid was shown in Figure $5 \mathrm{~d}$. The lipid content attained in sample WOET (ERFo) was $11.21 \pm 0.83 \%$ wt. Similar to the ETT and ERF, all the samples WET (ERF140-ERF240) had produced higher lipid content than in sample WOET. According to the chart bars, the lipid content extracted from Ankistrodesmus sp. increased from 140 to $18 \mathrm{oml} / \mathrm{min}$. Nevertheless, the lipid content had decreased from 180 to $240 \mathrm{ml} / \mathrm{min}$. The amount of lipid content extracted was the highest at $18 \mathrm{oml} / \mathrm{min}$ of 
recycling flowrate with $15.60 \pm 0.67 \%$ wt. and lowest at $14 \mathrm{Oml} / \mathrm{min}$ of recycling flowrate with $12.32 \pm 0.94 \%$ wt.

The entire lipid content gained from samples WET (ERF140-ERF240) were also found to be higher than the sample WOET. From these chart bars, increasing the ERF at a certain level will also increase the lipid extraction efficiency. The results gained in this study agreed with Daghrir and co-workers. They had investigated the effect of recycling flowrate towards the Chlorella vulgaris lipid extraction. At 340ml/min, the lipid obtained was 3.33\% wt., whereas at $440 \mathrm{ml} / \mathrm{min}$ lipid obtained was increased to $4.81 \%$ wt. at constant 0.5A for 60 min (Daghrir et al., 2014). Introducing the recycling flow in the ET has given advantages of the microalga cells to pass through the electric field region and enhanced the mass transfer coefficient. Furthermore, by increasing the recycling flow is capable of reducing the diffusion layer thickness near the anode (decrease the microalga cells precipitation), therefore provides better performance of the ET (Straessner et al., 2016).

Even so, increasing the ERF above than $180 \mathrm{ml} / \mathrm{min}$ had led to the decreasing of extraction of the microalga lipid content. Some cell disruption methods such as bead mill had shown a reduction of cell disruption of Saccharomyces cerevisiae if high flowrate was employed (Middelberg, 1995). This was because, when the feed flow rate increases the residence time of the microalga cells to pass through the electric field region will be reduced. Thereby, it may decrease the contact time of Ankistrodesmus sp. cells to be exposed by these electric fields. By means, high possibility of reversible electroporation mechanism will occur. In this way, ERF may affect the lipid extraction process.

Note that, the amount of lipid content obtained from the control samples (ETTo, EFSo and ERFo) were all different because all the microalga cells were harvested at the same day, but the lipid extraction was not performed at the same day. The ET method was carried out one at a time and not in a parallel experiment. For each parameter, including the replicates (from ET method to FAME determination experiment), it required at least five days to be completed. The first parameter conducted was the ETT, followed by EFS and ERF. Because of this, it was suspected that the lipid content of microalga might be changed due to this condition. Therefore, for each parameter, it has its control sample, as this was to ensure the culture sample for each parameter must be the same condition as possible and avoiding from attaining bias results.
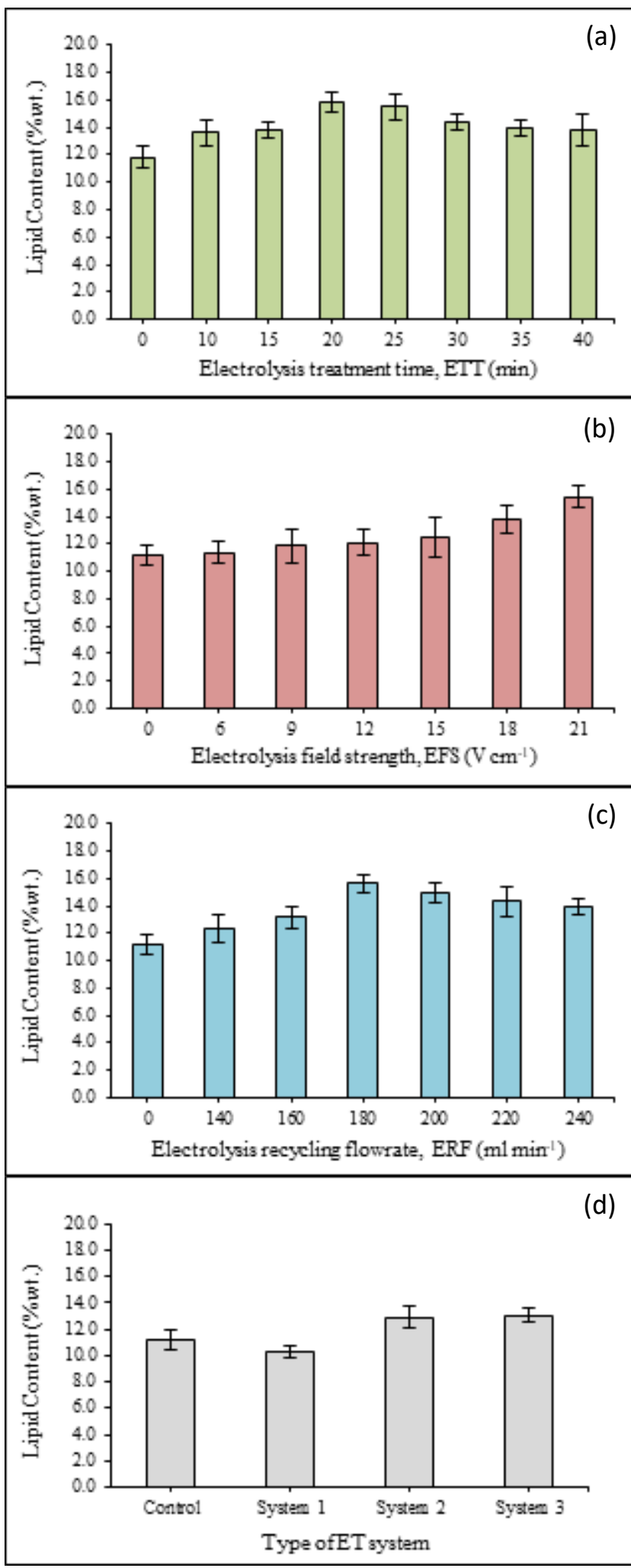

Figure 5. Effect of (a) ET systems, (b) ETT, (c) EFS and (d) ERF on the lipid extraction of Ankistrodesmus sp. 


\section{Comparison of Other Alternative Extraction Processes}

The comparison of other alternative lipid extraction processes with several of microalgae species are presented in Table 2. This includes the ET method, electrochemical treatment, PEF, microwave irradiation, ultrasonication, hydrothermal treatment and Soxhlet extraction. From Table 2, it was found that of all these methods the hydrothermal treatment has demonstrated to provide the highest lipid extraction with $84 \%$ wt. of Nannochloropsis sp. that was approximately $54 \%$ of lipid increment (Qu et al., 2018). This can be attributed by using high temperature (i.e. $180^{\circ} \mathrm{C}$ ) which can certainly destroy the cell wall of microalga. However, using this method may change the colour of microalga from dark green to brown and longer treatment time is needed (i.e. $60 \mathrm{~min}$ ) to achieve the highest lipid extraction. Other researchers like Yao et al. (2018) had also used an ultrasonication method to extract Nannochloropsis sp. lipid. It was reported that the extracted lipid was $73.2 \pm$ $8.4 \%$ wt. This method is currently under developing for large scale production.

Other than this extraction method, it was found that using the reactive electrochemical had improved the lipid extraction of $S$. dimorphus up to $23.4 \pm 0.7 \%$ wt. with $8.2 \%$ of lipid increased (Hua et al., 2016). The type of electrode material used (i.e. $\mathrm{Ti}_{4} \mathrm{O}_{7}$ ) is one of the factors that affect the lipid extraction performance. On the other hand, to convert $\mathrm{Ti}_{4} \mathrm{O}_{7}$ from $\mathrm{TiO}_{2}$ involves very high temperature at $900^{\circ} \mathrm{C}$, which extremely dangerous and requires a proper place for experimenting. According to Bensalem et al. (2018), the lipid of $C$. reinhardtii can be extracted up to $88.2 \pm 2.0 \%$, which an increased about $6.8 \%$ as compared to the PEF untreated sample. The findings also revealed that the cell disruption method, such as PEF is necessary prior to solvent extraction for extracting the lipid from $C$. reinhardtii. Nevertheless, it was also discovered that exposing $5.5 \mathrm{Kv} / \mathrm{cm}$ on the cell did not lyse or weaken the cell wall of $C$. reinhardtii (wild type strain).

Meanwhile, Tetraselmis sp. lipid can be extracted around $5.4 \%$ at $65^{\circ} \mathrm{C}$ for $10 \mathrm{~min}$ using the microwave irradiation assisted extraction (Teo and Idris, 2014). The small lipid content might due to the small volume of the sample was used in their study. However, by comparing with the present study, the lipid extracted percentage here was 2.9 times higher. Interestingly, some of the extraction methods presented in Table 2 such as Soxhlet extraction and electrochemical treatment have shown lower lipid extraction than the untreated microalgae (Daghrir et al., 2014; Escorsim et al., 2018). A. obliquus and C. vulgaris lipid can be extracted at $6.76 \pm 0.17 \%$ wt. and $5.53 \pm 0.23 \%$ wt. using Soxhlet extraction and electrochemical treatment, respectively. However, the final lipid extracted were both slightly lower than the untreated sample. The previous study conducted by Mansa et al. (2018b) also reported that the lipid extracted from Chlorella sp. at $14 \mathrm{~V} / \mathrm{cm}$ for $50 \mathrm{~min}$ using electrolysis treatment was slightly lower than the ETuntreated microalga.

Based on Table 2, it is shown that using different lipid extraction method with a variety of microalga species will offer dissimilar extraction performances. However, the findings obtained here are comparable with other extraction methods (i.e. Soxhlet extraction, microwave irradiation and electrochemical treatment). Perhaps, further investigation regards to the volume of microalga need be done for this ET method to become practicable in a large scale application for biodiesel production.

Table 2. Comparison of the proposed ET method with other alternative extraction processes

\begin{tabular}{|l|l|l|l|}
\hline Methods & Parameters & Optimum values & Reference \\
\hline Electrolysis & Microalga species & Ankistrodesmus $\mathrm{sp}$. & Present study \\
Treatment (ET) & Initial lipid content & $11.21 \pm 0.83 \% \mathrm{wt.}$ & \\
& Final lipid content & $15.60 \pm 0.67 \% \mathrm{wt}$. & \\
& Field strength & $21 \mathrm{~V} / \mathrm{cm}$ & \\
& Current intensity & $2.50 \pm 0.01 \mathrm{~A}$ & \\
& Treatment time & $20 \mathrm{~min}$ & $180 \mathrm{ml} / \mathrm{min}$ \\
& Recycling flow &
\end{tabular}




\begin{tabular}{|c|c|c|c|}
\hline & $\begin{array}{l}\text { Microalga conc. } \\
\text { Electrode type } \\
\text { Solvent extraction }\end{array}$ & $\begin{array}{l}1.00 \pm 0.03 \mathrm{~g} / \mathrm{l} \\
\text { Stainless steel (cathode and anode) } \\
\text { Folch method }\end{array}$ & \\
\hline $\begin{array}{l}\text { Electrolysis } \\
\text { Treatment (ET) }\end{array}$ & $\begin{array}{l}\text { Microalga species } \\
\text { Initial lipid content } \\
\text { Final lipid content } \\
\text { Field strength } \\
\text { Current intensity } \\
\text { Treatment time } \\
\text { Recycling flow } \\
\text { Microalga conc. } \\
\text { Electrode type } \\
\text { Solvent extraction }\end{array}$ & $\begin{array}{l}\text { Chlorella sp. } \\
8.58 \pm 0.49 \% \text { wt. } \\
7.72 \pm 0.54 \% \text { wt. } \\
14 \mathrm{~V} / \mathrm{cm} \\
1.92 \pm 0.02 \mathrm{~A} \\
50 \mathrm{~min} \\
140 \mathrm{ml} / \mathrm{min} \\
0.46 \pm 0.01 \mathrm{~g} / \mathrm{l} \\
\text { Stainless steel (cathode and anode) } \\
\text { Folch method }\end{array}$ & $\begin{array}{lll}\text { (Mansa } & \text { et } & a l ., \\
2018 b) & & \end{array}$ \\
\hline $\begin{array}{l}\text { Reactive } \\
\text { Electrochemical }\end{array}$ & $\begin{array}{l}\text { Microalga species } \\
\text { Initial lipid content } \\
\text { Final lipid content } \\
\text { Field strength } \\
\text { Current intensity } \\
\text { Treatment time } \\
\text { Microalga conc. } \\
\text { Electrode type } \\
\text { Solvent extraction }\end{array}$ & $\begin{array}{l}\text { Scenedesmus dimorphus } \\
15.2 \pm 0.6 \% \text { wt. } \\
23.4 \pm 0.7 \% \text { wt. } \\
8 \mathrm{~V} / \mathrm{cm} \\
0.5 \mathrm{~A} \\
120 \mathrm{~min} \\
1.4 \mathrm{~g} / \mathrm{l} \\
\text { Stainless steel (cathode) and } \mathrm{Ti}_{4} \mathrm{O}_{7} \text { (anode) } \\
\text { Dichloromethane and methanol }\end{array}$ & (Hua et al., 2016) \\
\hline Electrochemical & $\begin{array}{l}\text { Microalga species } \\
\text { Initial lipid content } \\
\text { Final lipid content } \\
\text { Field strength } \\
\text { Current intensity } \\
\text { Treatment time } \\
\text { Recycling flow } \\
\text { Electrode type } \\
\text { Solvent extraction } \\
\text { Electrolyte }\end{array}$ & $\begin{array}{l}\text { Chlorella vulgaris } \\
6.23 \pm 1.05 \% \text { wt. } \\
5.53 \pm 0.23 \% \text { wt. } \\
14.3 \mathrm{~V} / \mathrm{cm} \\
0.6 \mathrm{~A} \\
100 \mathrm{~min} \\
394.51 \mathrm{ml} / \mathrm{min} \\
\text { Stainless steel (cathode) and } \mathrm{Ti} / \mathrm{IrO}_{2} \text { (anode) } \\
\text { Folch method } \\
1.4 \mathrm{~g} / \mathrm{l} \text { of } \mathrm{Na}_{2} \mathrm{SO}_{4}\end{array}$ & $\begin{array}{l}\text { (Daghrir et al., } \\
\text { 2014) }\end{array}$ \\
\hline $\begin{array}{l}\text { Pulsed Electric } \\
\text { Field (PEF) }\end{array}$ & $\begin{array}{l}\text { Microalga species } \\
\text { Initial lipid content } \\
\text { Final lipid content } \\
\text { Field strength } \\
\text { Frequency } \\
\text { Pulse duration } \\
\text { Number of pulses } \\
\text { Microalga volume } \\
\text { Electrode type } \\
\text { Solvent extraction }\end{array}$ & $\begin{array}{l}\text { Chlamydomonas reinhardtii } \\
81.4 \pm 2.3 \%^{\mathrm{a}} \\
88.2 \pm 2.0 \%^{\mathrm{a}} \\
5.5 \mathrm{Kv} / \mathrm{cm} \\
10 \mathrm{~Hz} \\
5 \mu \mathrm{s} \\
10 \mathrm{unipolar} \\
130 \mu \mathrm{l}\left(3 \times 10^{6} \text { cells } / \mathrm{ml}\right) \\
\text { Stainless steel (cathode and anode) } \\
\text { Hexane }\end{array}$ & $\begin{array}{l}\text { (Bensalem et al., } \\
\text { 2018) }\end{array}$ \\
\hline
\end{tabular}




\begin{tabular}{|c|c|c|c|}
\hline $\begin{array}{l}\text { Microwave } \\
\text { Irradiation }\end{array}$ & $\begin{array}{l}\text { Microalga species } \\
\text { Initial lipid content } \\
\text { Final lipid content } \\
\text { Power } \\
\text { Treatment } \\
\text { Temperature } \\
\text { Treatment time } \\
\text { Microalga volume } \\
\text { Solvent extraction }\end{array}$ & $\begin{array}{l}\text { Tetraselmis sp. } \\
\sim 5.0 \% \\
\sim 5.4 \%^{\mathrm{b}} \\
500 \mathrm{~W} \\
65^{\circ} \mathrm{C} \\
10 \mathrm{~min} \\
15 \mathrm{ml} \\
\text { Folch Method }\end{array}$ & $\begin{array}{l}\text { (Teo and Idris, } \\
\text { 2014) }\end{array}$ \\
\hline Ultrasonication & $\begin{array}{l}\text { Microalga species } \\
\text { Initial lipid content } \\
\text { Final lipid content } \\
\text { Frequency } \\
\text { Power density } \\
\text { Treatment time } \\
\text { Microalga mass } \\
\text { Solvent extraction }\end{array}$ & $\begin{array}{l}\text { Nannochloropsis sp. } \\
\text { Not stated } \\
73.2 \pm 8.4 \% \text { wt.c }^{c} \\
20 \mathrm{kHz} \\
3.8 \mathrm{~W} / \mathrm{ml} \\
5 \mathrm{~min} \\
3 \mathrm{~g}(12 \% \text { solid conc.) } \\
\text { n-hexane }\end{array}$ & (Yao et al., 2018) \\
\hline $\begin{array}{l}\text { Hydrothermal } \\
\text { Treatment }\end{array}$ & $\begin{array}{l}\text { Microalga species } \\
\text { Initial lipid content } \\
\text { Final lipid content } \\
\text { Treatment temperature } \\
\text { Treatment time } \\
\text { Microalga conc. } \\
\text { Solvent extraction }\end{array}$ & $\begin{array}{l}\text { Nannochloropsis sp. } \\
30.44 \pm 1.46 \% \text { wt. } \\
84 \% \text { wt. } \\
180^{\circ} \mathrm{C} \\
60 \text { min } \\
20 \% \text { wt. solid conc. } \\
\text { Diethyl ether }\end{array}$ & (Qu et al., 2018) \\
\hline $\begin{array}{l}\text { Soxhlet } \\
\text { Extraction }\end{array}$ & $\begin{array}{l}\text { Microalga species } \\
\text { Initial lipid content } \\
\text { Final lipid content } \\
\text { Treatment time } \\
\text { Microalga mass } \\
\text { Solvent }\end{array}$ & $\begin{array}{l}\text { Acutodesmus obliquus } \\
7.41 \pm 0.16 \% \text { wt. } \\
6.76 \pm 0.17 \% \text { wt. } \\
12 \mathrm{~h} \\
20 \mathrm{~g} \\
\text { Ethanol: Hexane }(1: 2 ; \mathrm{v} / \mathrm{v})\end{array}$ & $\begin{array}{l}\text { (Escorsim et al., } \\
\text { 2018) }\end{array}$ \\
\hline
\end{tabular}

Note: ${ }^{a}$ lipid extraction is expressed based on absorbance; ${ }^{b}$ lipid extraction is expressed in volume extracted lipid (ml) / cell dry weight (g); ${ }^{c}$ quantified based on the non-polar lipid

\section{Microscopy Results}

\section{Microscopic cell observation}

The Ankistrodesmus sp. cells samples before and after the ET method was viewed under a light microscope. This was to observe any physical changes, such as shapes or abnormal appearances. The microscopic images reported in this study were based on the highest lipid content attained in each ET parameter from ETT2O, EFS21 and ERF180 sample. The microscopic images for Ankistrodesmus sp. cells before the ET method were shown in Figure 6a. As observed, the Ankistrodesmus sp. cells have needle-like shaped in green colour and were found to be similar to other reported literature (Mansa et al., 2018a; Sukkrom, 2014).

Figure $6 b$, Figure $6 c$ and Figure $6 d$ displayed the microscopic images for Ankistrodesmus sp. cells after the ET method and were taken from the ETT20, EFS21 and ERF180 sample, respectively. Based on these microscopic images, the cells prior to ET method were intact (see Figure $6 a)$, and after the ET method, some cells did not have the 
needle-like form. Moreover, flocculated green materials without cell membranes were observed. These green materials were believed to be the intracellular material or the green pigment of Ankistrodesmus sp. Noted that, the sample's conductivity increased during the ET experiment (data not shown). The increasing conductivity indicates the presence of ionic compounds such as lipids, carbohydrates and proteins (Postma et al., 2016). Therefore, this shows that Ankistrodesmus sp. cell membrane may have been disrupted during the ET method.
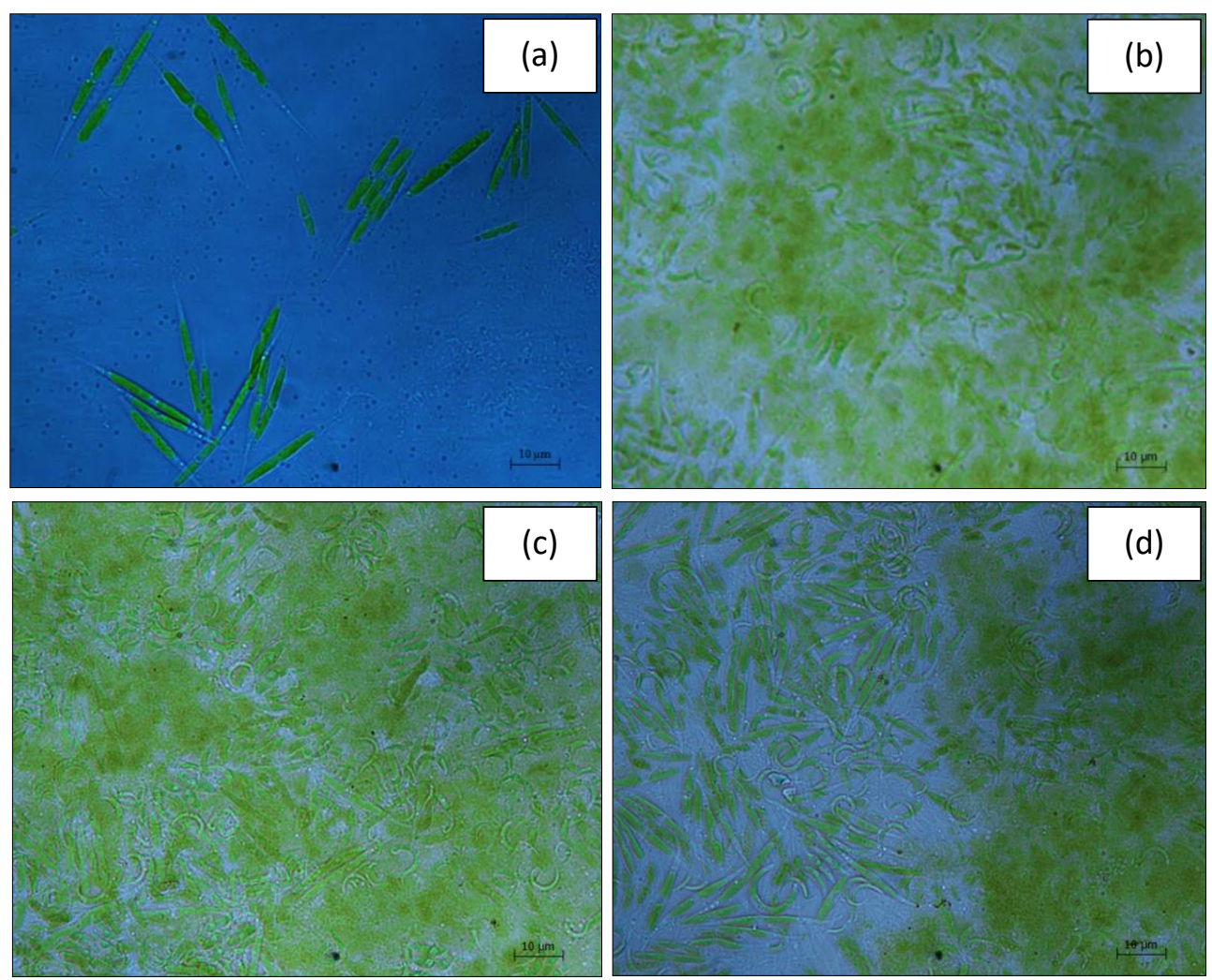

Figure 6. Ankistrodesmus sp. cells are taken from (a) sample WOET, (b), ETT20 (c) EFS21 and (d) ERF180 samples viewed under a light microscope at 40X magnification power

\section{Microalga cells morphology}

To support the microscopic observation results, the condition of Ankistrodesmus sp. cells before and after the ET method were also viewed under SEM to observe if any cells changes in term of sizes, shapes or appearances. The SEM images were taken from ETT20, EFS21 and ERF180 sample (based on the higher lipid content extraction). Figure 7a showed the SEM images for sample WOET and was viewed at $3000 \mathrm{X}$ magnification power. The cells have a needle-like shape and curvy or sharp extremes, as presented in Figure 6a. Moreover, some of the cells were observed to have irregular crests (see the white arrows) as shown in Figure $7 \mathrm{~b}$. The cell morphology observed here were similar to Ankistrodesmus gracilis (Asselborn et al., 2015).

Figure $7 \mathrm{~b}$ shows the SEM images from the ETT20 sample.
Based on these SEM images, some cells do not have their cell membrane (white arrows). The cells without membrane might be the green materials without membrane that were observed from the microscopic observation. These fragmented and agglomerated materials were believed to be the intracellular components of Ankistrodesmus sp., which were similar to Chlorella sp. (Yap et al., 2014). This shows that Ankistrodesmus sp. cells had been disrupted by the ET method.

Figure 7c shows the SEM images from the EFS21 sample. The images taken were also similar to Figure $7 \mathrm{~b}$, which some cells do not have their cell membrane (white arrows). It is believed to be the green materials without its cell membrane. Figure $7 \mathrm{~d}$ shows the SEM images from the ERFo.18 sample. Based on these SEM images, it was observed that some cells were fragmented and adhered with each other (see the white 
arrows). In addition, some cells have no sharp edges (see the white arrows), which were likely broken. Hence, these
SEM images supported the results obtained from the microscopic observation.
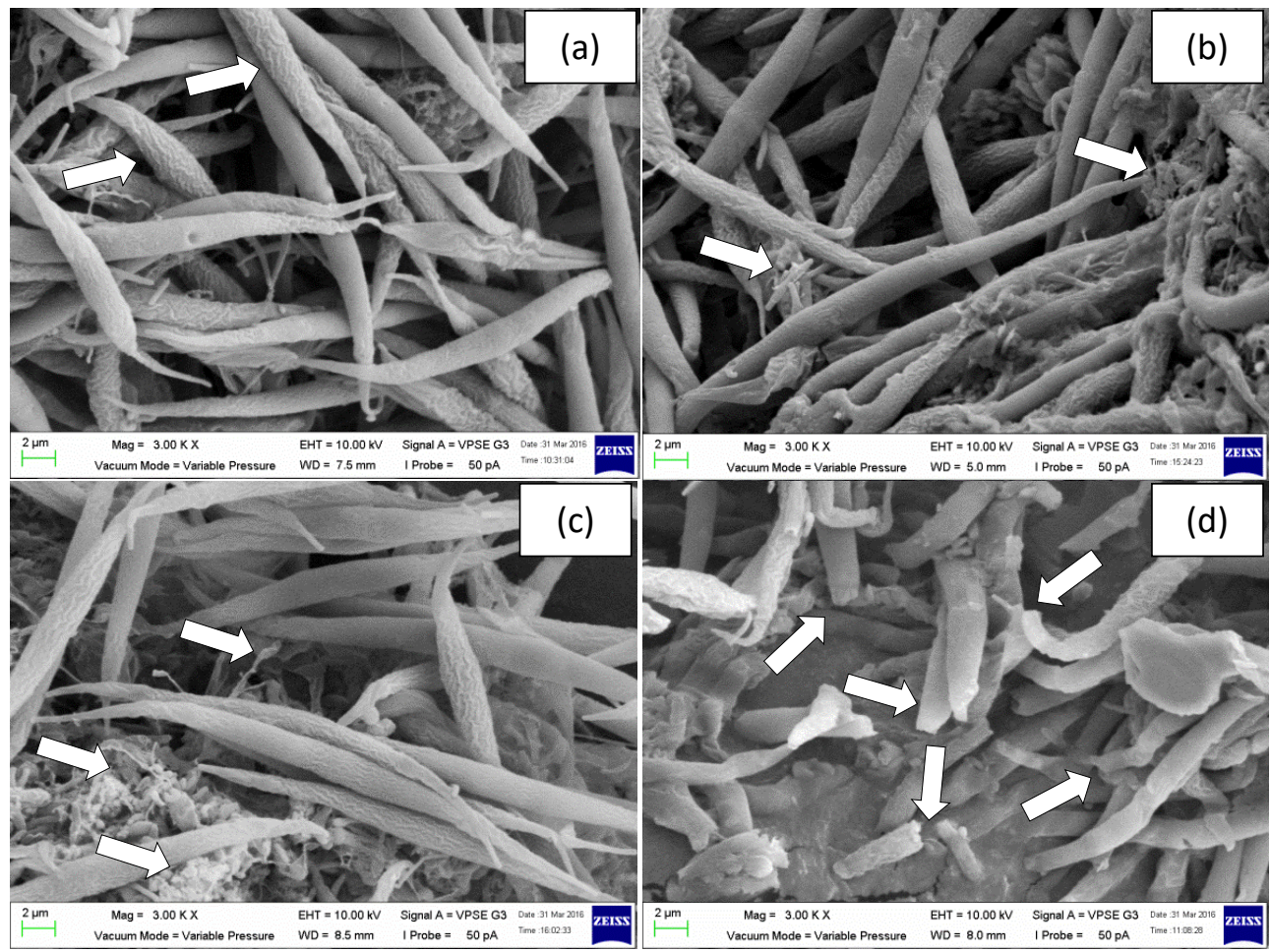

Figure 7. Ankistrodesmus sp. cells morphology taken from (a) sample WOET, (b) ETT20, (c) EFS21 and (d) ERF180 samples viewed under SEM at $3000 \mathrm{X}$ magnification power

\section{Fatty Acid Methyl Ester Compositions}

There were six significant peaks obtained from the GCMS chromatogram at the retention time of 16.08, 16.24, 16.95, 22.18, 22.40 and 22.82. The compounds detected from these six peaks were summarised in Table 2. However, only four peaks were confirmed as the FAME compounds. The four FAME detected were 7,10-hexadecadienoic acid methyl ester, hexadecanoic acid methyl ester (methyl palmitate), (E,E)-9,12-Octadecadienoic acid methyl ester (methyl linoleate) and (Z,Z,Z)-9,12,15-octadecatrienoic acid, methyl ester (methyl linolenate) at retention time 16.08, 16.95, 22.18 and 22.41, respectively. The number of peaks obtained here was the same as reported by Mansa et al. (2018a). From Table 3, among these six peaks, the compound detected at the retention time of 22.82 was dominated with $47.18 \%$, which was the $3,7,11,15^{-}$ tetramethyl-2-hexadecen-1-ol. Nevertheless, among the FAME compounds, methyl palmitate was the predominant compound with $15.78 \%$, followed by methyl linolenate,7,10hexadecadienoic acid methyl ester and methyl linoleate with $14.28 \%, 6.84 \%$ and $6.51 \%$, respectively.

Table 3. Compounds detected from Ankistrodesmus sp. WOET sample

\begin{tabular}{|l|l|l|l|}
\hline No. & \multicolumn{1}{|c|}{ Compound Name } & Retention Time (min) & Peak Area (\%) \\
\hline 1. & $7,10-$ hexadecadienoic acid methyl ester & 16.08 & 6.84 \\
\hline 2. & $(\mathrm{Z}, \mathrm{Z}, \mathrm{Z})-9,12,15-$ Octadecatrien-1-ol & 16.24 & 9.41 \\
\hline $3 \cdot$ & Hexadecanoic acid methyl ester & 16.95 & 15.78 \\
\hline $4 \cdot$ & (E,E)-9,12-Octadecadienoic acid methyl ester & 22.18 & 6.51 \\
\hline $5 \cdot$ & (Z,Z,Z)-9,12,15-Octadecatrienoic acid methyl ester & 22.41 & 14.28 \\
\hline 6. & $3,7,11,15-$ Tetramethyl-2-hexadecen-1-ol & 22.82 & 47.18 \\
\hline
\end{tabular}


Methyl palmitate consists of monosaturated fatty acids with carbon chain C16:0. Meanwhile, 7,10-hexadecadienoic acid methyl ester (two double bonds), methyl linoleate (two double bonds) and methyl linolenate (three double bonds) consist of polyunsaturated fatty acids with carbon chain C16:2, C18:2 and C18:3, respectively. The result obtained in this study agreed with the findings obtained by Sukkrom (2014), which has stated that palmitic acid (C16:0) was majorly found in Ankistrodesmus sp. lipid. The saturated fatty acids such as palmitic acid are favourable in biodiesel engine (Knothe \& Razon, 2017). As for monounsaturated and polyunsaturated fatty acids, additional processes will be required to convert them into saturated fatty acids (Fuad et al., 2015). Hence, adding an extra cost for the biodiesel conversion process.

The amount of methyl palmitate concentration in each ETT samples is shown in Figure 8a. For sample WOET, the methyl palmitate obtained was $0.113 \pm 0.018 \mu \mathrm{g} / \mathrm{ml}$. The methyl palmitate extracted was the highest at 20 min with $0.440 \pm 0.046 \mu \mathrm{g} / \mathrm{ml}$ and lowest at $10 \mathrm{~min}$ with $0.254 \pm$ $0.067 \mu \mathrm{g} / \mathrm{ml}$ at constant EFS $(21 \mathrm{~V} / \mathrm{cm})$ and ERF (140ml/min). The highest methyl palmitate attained in ETT2O can be correlated to the higher lipid content was also extracted at this point. Meanwhile, the decreasing of methyl palmitate can be attributed by lipid oxidation as previously discussed. Apart from that, several factors such as the type of fatty acids, oxygen, heat, photo-sensitivity and the existence of minor constitutes (i.e. metals, phospholipids, free fatty acids, monoacylglycerol and triacylglycerol) can affect the chemical reactions in lipid to biodiesel (Meullemiestre et al., 2016).

The amount of methyl palmitate concentration in each ETT samples was shown in Figure 8b. For sample WOET the methyl palmitate obtained was $0.145 \pm 0.010 \mu \mathrm{g} / \mathrm{ml}$. The methyl palmitate concentration extracted was the highest at $21 \mathrm{~V} / \mathrm{cm}$ with $0.629 \pm 0.058 \mu \mathrm{g} / \mathrm{ml}$ and lowest at $6 \mathrm{~V} / \mathrm{cm}$ with $0.250 \pm 0.040 \mu \mathrm{g} / \mathrm{ml}$ at constant ETT $(20 \mathrm{~min})$ and ERF $(140 \mathrm{ml} / \mathrm{min})$. The highest methyl palmitate attained in EFS21 can be correlated to the higher lipid content was also extracted at this point. The amount of methyl palmitate concentration in each ERF samples was shown in Figure 8c. For sample WOET, the methyl palmitate obtained was $0.176 \pm 0.019 \mu \mathrm{g} / \mathrm{ml}$. The methyl palmitate extracted was the highest at $180 \mathrm{ml} / \mathrm{min}$ with $0.390 \pm 0.022 \mu \mathrm{g} / \mathrm{ml}$ and lowest at $140 \mathrm{ml} / \mathrm{min}$ with $0.252 \pm 0.023 \mu \mathrm{g} / \mathrm{ml}$ at constant ETT (20 $\mathrm{min})$ and EFS $(21 \mathrm{~V} / \mathrm{cm})$. The highest methyl palmitate attained in ERF21 can be correlated to the higher lipid content was also extracted at this point.

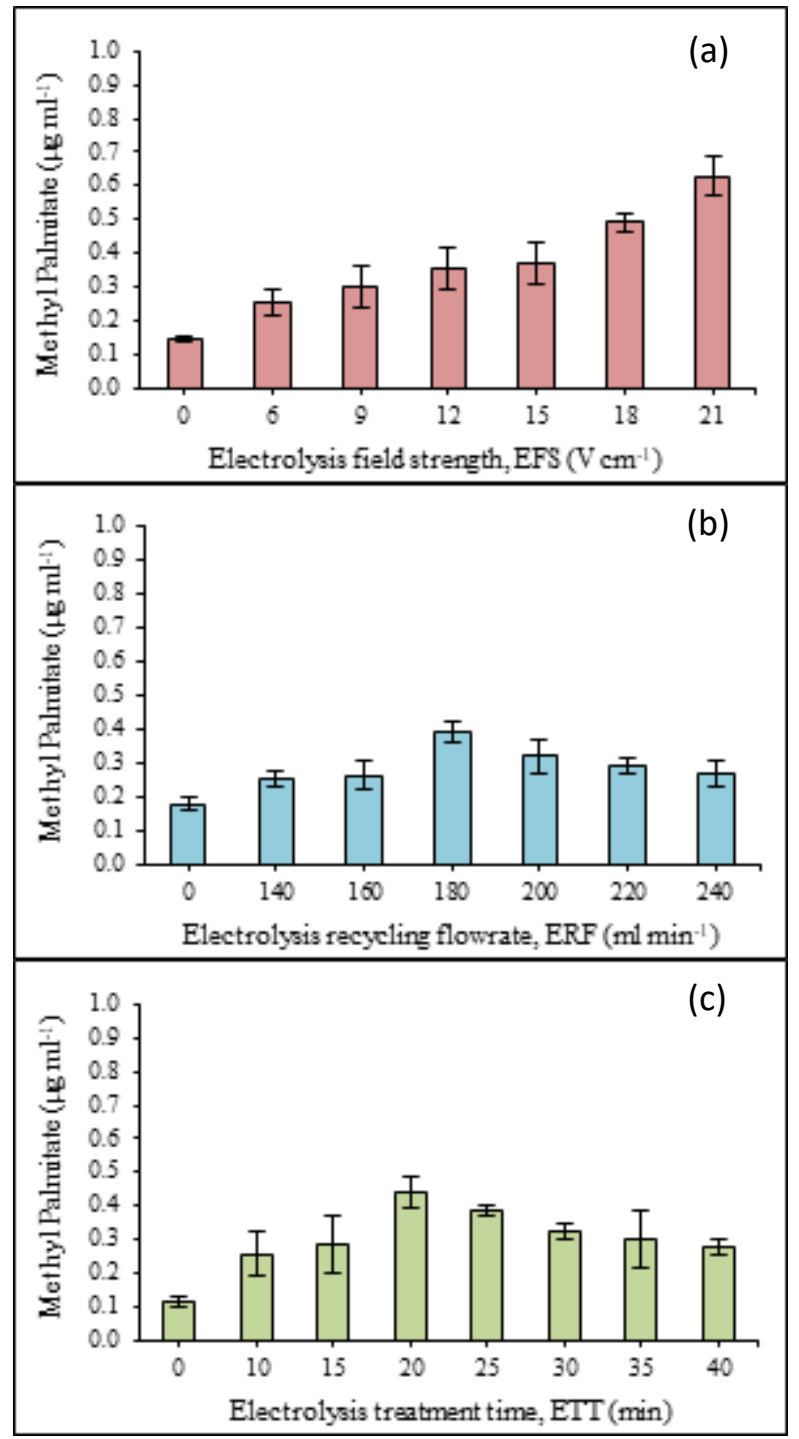

Figure 8. Effect of (a) ETT, (b) EFS and (c) ERF on the FAME of Ankistrodesmus sp.

\section{CONCLUSION}

In this study, the effect of ETT, EFS and ERF towards the lipid extraction of Ankistrodesmus sp. were investigated. All samples from ETT, EFS and ERF that had undergone ET have produced higher lipid content than the control sample with an increase of lipid extraction from 1.34 to 1.40 times higher. Furthermore, it was shown that using the ET method prior to solvent extraction did not affect the FAME qualities 
at all. Besides, it was also revealed that Ankistrodesmus sp. contained higher saturated fatty acids such as palmitic acid (C16:0), and this is a crucial feature in one of the biodiesel properties. This elucidated that using ET as the microalga pre-treatment for lipid extraction not only enhance the lipid extraction yield but also proven to sustain the quality of FAME compositions. Aside from being conventionally utilized in the microalga harvesting process, the ET could also be one of the alternative methods that can be used to distract the microalga's cell wall, especially for wet biomass in biodiesel production. The parameters such as the microalga concentration, microalga species types, solvent types and electrode types can be investigated for the improvement of lipid extraction using the ET method.

\section{ACKNOWLEDGEMENTS}

The authors would like to thank the Universiti Malaysia Sabah for the financial support provided through SBKo235-TK-2015 and the Ministry of Agriculture Malaysia through GPRL 017 (Biochemical Process of Seaweed for Industrial Product).

\section{REFERENCES}

[1] Asselborn, V, Fernández, C, Zalocar, Y \& Parodi, ER 2015, 'Effects of Chlorpyrifos on the growth and ultrastructure of green algae, Ankistrodesmus gracilis', Ecotoxicology and Environmental Safety, vol. 120, pp. 334-341.

[2] Baierle, F, John, DK, Souza, MP, Bjerk, TR, Moraes, MSA, Hoeltz, M, Rohlfes, ALB, Camargo, ME, Corbellini, VA \& Schneider, RCS 2015, 'Biomass from microalgae separation by electroflotation with iron and aluminum spiral electrodes', Chemical Engineering Journal, vol. 267, pp. 274-281.

[3] Bartošová, A, Blinová, L \& Gerulová, K 2015, 'Characterisation of polysaccharides and lipids from selected green algae species by FTIR-ATR Spectroscopy', Faculty of Materials Science and Technology Slovak University of Technology, vol. 23, no. 36, pp. 97-102.

[4] Bensalem, S, Lopes, F, Bodénès, P, Pareau, D, Français, O \& Le, B 2018, 'Understanding the mechanisms of lipid extraction from microalga Chlamydomonas reinhardtii after electrical field solicitations and mechanical stress within a microfluidic device', Bioresource Technology, vol. 257, pp. 129-136.

[5] Daghrir, R, Igounet, L, Brar, SK \& Drogui, P 2014, 'Novel electrochemical method for the recovery of lipids from microalgae for biodiesel production', Journal of the Taiwan Institute of Chemical Engineers, vol. 45, no. 1, pp. 153-162.

[6] Dean, AP, Sigee, DC, Estrada, B \& Pittman, JK 2010, 'Using FTIR spectroscopy for rapid determination of lipid accumulation in response to nitrogen limitation in freshwater microalgae', Bioresource Technology, vol. 101, pp. 4499-4507.

[7] Donsì, F, Ferrari, G \& Pataro, G 2010, 'Applications of pulsed electric field treatments for the enhancement of mass transfer from vegetable tissue', Food Engineering Reviews, vol. 2, pp. 109130.

[8] Eing, C, Goettel, M, Straessner, R, Gusbeth, C \& Frey, W 2013, Pulsed electric field treatment of microalgae - Benefits for microalgae biomass processing', IEEE Transactions on Plasma Science, vol. 4, no. 10, pp. 2901-2907.

[9] Escorsim, AM, Rocha, GD, Vargas, JVC, Mariano, AB, Ramos, LP, Corazza, ML, \& Cordeiro, CS 2018, 'Biomass and bioenergy extraction of Acutodesmus obliquus lipids using a mixture of ethanol and hexane as solvent', Biomass and Bioenergy, vol. 108, pp. 470-478.

[10] Folch, J, Lees, M, \& Sloane-Stanley, GH 1957, 'A simple method for the isolation and purification of total lipids from animal tissues', Journal of 
Biological Chemistry, no. 226, pp. 497-509.

[11] Forfang, K, Zimmermann, B, Kosa, G, Kohler, A \& Shapaval, V 2017, 'FTIR spectroscopy for evaluation and monitoring of lipid extraction efficiency for oleaginous fungi', Plos One, vol. 12, no. 1, pp. 1-17.

[12] Fuad, MAM, Mohammad-Noor, N, Jalal, AKC \& Kamaruzzaman, BY 2015, 'Growth profile and fatty acid accumulation of four Chaetoceros Taxa isolated from coastal water of Pahang, Malaysia', Sains Malaysiana, vol. 44, no. 8, pp. 1077-1084.

[13] Guldhe, A, Misra, R, Singh, P, Rawat, I \& Bux, F 2016, 'An innovative electrochemical process to alleviate the challenges for harvesting of small size microalgae by using non-sacrificial carbon electrodes', Algal Research, vol. 19, pp. 292-298.

[14] Günerken, E, D’Hondt, E, Eppink, MHM, GarciaGonzalez, L, Elst, K \& Wijffels, RH 2015, 'Cell disruption for microalgae biorefineries', Biotechnology Advances, no. 33, pp. 243-26o.

[15] Heinz, V, Toepfl, S \& Knorr, D 2003, 'Impact of temperature on lethality and energy efficiency of apple juice pasteurization by pulsed electric fields treatment', Innovative Food Science and Emerging Technologies, vol. 4, pp. 167-175.

[16] Hua, L, Guo, L, Thakkar, M, Wei, D, Agbakpe, M, Kuang, L, Magpile, M, Chaplin, BP, Tao, Y, Shuai, D, Zhang, X, Mitra, S \& Zhang, W 2016, 'Effects of anodic oxidation of a substoichiometric titanium dioxide reactive electrochemical membrane on algal cell destabilization and lipid extraction', Bioresource Technology, vol. 203, pp. 112-117.

[17] Huang, K. \& Wang, J 2009, 'Designs of pulsed electric fields treatment chambers for liquid foods pasteurization process: A review', Journal of Food Engineering, vol. 95, pp. 227-239.

[18] IEA 2017, Market Report Series Energy Efficiency 2017.

[19] Joannes, C, Mansa, RF, Sipaut, CS, Yasir, SM \& Dayou, J 2016, 'Comparative studies of cell growth of freshwater microalga Chlorella sp. in photoautotrophic, heterotrophic and mixotrophic cultures', Jurnal Teknologi (Science \&
Engineering), vol. 78, no. 7, pp. 83-89.

[20] Joannes, C, Sipaut, CS, Dayou, J, Yasir, SM \& Mansa, RF 2015a, 'Review paper on cell membrane electroporation of microalgae using electric field treatment method for microalgae lipid extraction', IOP Conference Series: Materials Science and Engineering, vol. 78, pp. 1-8.

[21] Joannes, C, Sipaut, CS, Dayou, J, Yasir, SM \& Mansa, RF 2015b, 'The potential of using pulsed electric field (PEF) technology as the cell disruption method to extract lipid from microalgae for biodiesel production', International Journal of Renewable Energy Research, vol. 5, no. 2, pp. $598-621$.

[22] Knothe, G \& Razon, LF 2017, 'Biodiesel fuels', Progress in Energy and Combustion Science, vol. 58 , pp. 36-59.

[23] Lee, SY, Cho, JM, Chang, YK. \& Oh, YK. 2017, 'Cell disruption and lipid extraction for microalgal biorefineries: A review', Bioresource Technology, vol. 244, pp. 1317-1328.

[24] Mansa, RF, Sipaut, CS, Yasir, S, Dayou, J \& Joannes, C 2018a, 'Comparative studies of cell growth, total lipid and methyl palmitate of Ankistrodesmus sp. in phototrophic, mixotrophic and heterotrophic cultures for biodiesel production', International Journal of Renewable Energy Research, vol. 8, no. 1, pp. 438-450.

[25] Mansa, RF, Sipaut, CS, Yasir, S, Dayou, J \& Joannes, C 2018b, 'A feasibility study using electrolysis treatment (ET) as the pre-treatment method to extract lipid from Chlorella sp. for biodiesel Production', Pertanika Journal of Science and Technology, vol. 26, no. 4, pp. 1693-1712.

[26] Mansa, RF, Tahir, A, Hua, LM, Dayou, J \& Sipaut, CS 2012, 'Design of a pilot scale outdoor photobioreactor for mass cultivation of local microalga', International Journal of Engineering and Physical Sciences, vol. 6, pp. 348-352.

[27] Meullemiestre, A, Breil, C, Abert-Vian, M \& Chemat, F 2016, 'Microwave, ultrasound, thermal treatments, and bead milling as intensification techniques for extraction of lipids from oleaginous 
Yarrowia lipolytica yeast for a biojetfuel application', Bioresource Technology, vol. 211, pp. 190-199.

[28] Middelberg, APJ 1995, 'Process-scale disruption of microorganisms', Biotechnology Advances, vol. 13, no. 3, pp. 491-551.

[29] Misra, R, Guldhe, A, Singh, P, Rawat, I \& Bux, F 2014, 'Electrochemical harvesting process for microalgae by using nonsacrificial carbon electrode: A sustainable approach for biodiesel production', Chemical Engineering Journal, vol. 255, pp. 327-333.

[30] Misra, R, Guldhe, A, Singh, P, Rawat, I, Stenström, TA \& Bux, F 2015, 'Evaluation of operating conditions for sustainable harvesting of microalgal biomass applying electrochemical method using non sacrificial electrodes', Bioresource Technology, vol. 176 , pp. 1-7.

[31] Mubarak, M, Shaija, A \& Suchithra, TV 2015, 'A review on the extraction of lipid from microalgae for biodiesel production', Algal Research, vol. 7, pp. 117-123.

[32] Ortega-Rivas, E 2012, Non-thermal Food Engineering Operations, Springer, New York.

[33] Postma, PR, Pataro, G, Capitoli, M, Barbosa, MJ, Wijffels, RH, Eppink, MHM, Olivieri, G \& Ferrari, G 2016, 'Selective extraction of intracellular components from the microalga Chlorella vulgaris by combined pulsed electric field-temperature treatment', Bioresource Technology, vol. 203, pp $80-88$.

[34] Qu, Z, Zeng, J, Zhang, Y, Liao, Q, Sharma, BK, Fu, Q, Huang, Y, \& Liu, Z 2018, 'Hydrothermal cell disruption of Nannochloropsis sp. and its influence on lipid extraction', Algal Research, vol. 35, pp. 407-415.

[35] Rego, D, Costa, L, Pereira, MT \& Redondo, LM 2015, 'Cell membrane permeabilization studies of Chlorella sp. by pulsed electric fields', IEEE Transactions on Plasma Science, vol. 43, no. 10, pp 3483-3488.

[36] Straessner, R, Silve, A, Eing, C, Rocke, S, Wuestner, R, Leber, K, Mueller, G \& Frey, W 2016,
'Microalgae precipitation in treatment chambers during pulsed electric field (PEF) processing', Innovative Food Science and Emerging Technologies, vol. 37, pp. 391-399.

[37] Sukkrom, K. 2014, 'Biomass and lipid production from green microalga Ankistrodesmus sp.', $\mathrm{PhD}$ Thesis, King Mongkut's University of Technology Thonburi, Thailand.

[38] Sukkrom, K, Bunnag, B \& Pavasant, P 2014, 'Study of Increasing Lipid Production from Reused Medium for Ankistrodesmus sp. Culture', 3rd International Conference on Informatics, Environment, Energy and Applications, vol. 66, pp. 41-45.

[39] Teo, CL, \&Idris, A 2014, 'Enhancing the various solvent extraction method via microwave irradiation for extraction of lipids from marine microalgae in biodiesel production', Bioresource Technology, vol. 171, pp. 477-481.

[40] Uduman, N, Bourniquel, V, Danquah, MK \& Hoadley, AFA 2011, 'A parametric study of electrocoagulation as a recovery process of marine microalgae for biodiesel production', Chemical Engineering Journal, vol. 174, no.1, pp. 249-257.

[41] Uduman, N, Qi, Y, Danquah, MK, Forde, GM \& Hoadley, A 2010, 'Dewatering of microalgal cultures: A major bottleneck to algae-based fuels', Journal of Renewable and Sustainable Energy, vol. 2, no. 1, pp. 1-15.

[42] Yao, S, Mettu, S, Martin, GJO, Law, SQK, \& Ashokkumar, M 2018, 'The effect of high-intensity ultrasound on cell disruption and lipid extraction from high-solids viscous slurries of Nannochloropsis sp. biomass', Algal Research, vol. 35, pp. 341-348.

[43] Yap, BHJ, Crawford, SA, Dumsday, GJ, Scales, PJ \& Martin, GJO 2014, 'A mechanistic study of algal cell disruption and its effect on lipid recovery by solvent extraction', Algal Research, vol. 5, no. 1, pp 112-120.

[44] Zbinden, MDA, Sturm, BSM, Nord, RD, Carey, WJ, Moore, D, Shinogle, H \& Stagg-Williams, SM 2013, 'Pulsed electric field (PEF) as an intensification 
pretreatment for greener solvent lipid extraction

from microalgae', Biotechnology and

Bioengineering, vol. 110, no. 6, pp 1605-1615.

[45] Zhou, W, Gao, L, Cheng, W, Chen, L, Wang, J, Wang, H, Zhang, W \& Liu, T 2016, 'Electroflotation of Chlorella sp. assisted with flocculation by chitosan', Algal Research, vol. 18, pp. 7-14.

[46] Zimmermann, U, Pilwat, G \& Riemann, F 1974, 'Dielectric breakdown of cell membranes', Biophysical Journal, vol. 14, pp. 881-899. 